Turyzm 2005, $\quad 15 / 1-2$

Maciej Ostrowski ks.

Katedra Teologii Pastoralnej Szczegółowej

Papieska Akademia Teologiczna

W Krakowie

atostrow@cyf-kr.edu.pl

\section{POMIĘDZY SACRUM A PROFANUM - O TURYSTYCE W SAKRALNYCH OBIEKTACH}

Zarys treści: Autor opisuje teologiczny sens istnienia sakralnych budowli, których pierwszym przeznaczeniem jest kult, nie tylko bycie obiektem kultury. Podkreśla wychowawcza rolę turystyki w obszarze kultury i religii. Zadaniem animatorów turystyki jest pomoc w odkrywaniu sacrum i rozbudzanie szacunku do sacrum. Autor sprzeciwia się ograniczaniu turystyki do roli produktu.

Stowa kluczowe: sacrum, profanum, turystyka, sakralny obiekt, kościół, papież.

Zacznijmy artykuł od pewnej praktycznej obserwacji. Otóż na drzwiach zabytkowego kościoła w turystycznej miejscowości autor zauważył tablicę w formie piktogramów skierowaną do turystów: „zakaz wejścia z lodami, zakaz wprowadzania psów, zakaz palenia papierosów”. Obok znalazło się inne zdanie: „Jesteś w domu Bożym, miejscu modlitwy". Przyzwyczailiśmy się przy drzwiach świątyń raczej do napisów przypominających o zachowaniu ciszy bądź kulturalnym ubiorze. Przy masowym napływie bardzo zróżnicowanych poziomem kultury turystów dziś już widocznie forma ta nie wystarcza. $Z$ drugiej strony, zastanawiające jest, że analogiczne prośby i ostrzeżenia rzadziej znajdujemy na drzwiach muzeów, sal koncertowych i teatralnych. Czy jest to wynikiem wyłącznie tego, że stoją tam portierzy i ochroniarze filtrujący przybyszów? Zdaje się, iż zmienia się Współczesny człowiek. Już nie tylko obniża się poziom osobistej kultury, ale człowiekowi brakuje poczucia sacrum.

Znamienita część turystycznego ruchu przyjmuje za cel odwiedziny miejsc związanych $\mathrm{z}$ religią. Czy można umieścić je $w$ jednym rzędzie

\section{BETWEEN SACRUM AND PROFANUM: TOURISM IN SACRED SITES}

Abstract: The author describes the theological significance of sacred sites whose primary function is as a cult, not a cultural site. He stresses the educational role of tourism as regards culture and religion while a tourism organisers' task can be to help discover the sacrum and teach respect for it. The author is opposed to the reduction of tourism to simply sightseeing.

Key words: sacrum, profanum, tourism, sacred site, the church, the papacy.

Let us begin the article with a certain practical observation. On the door of an old church in a tourism destination the author noticed a board with information in the form of pictograms, addressed to tourists: "no entry with ice-cream", "no dogs", "no smoking". Next to it there was another: "You are in the God's house, a place of prayer". We have become used to finding notices on church doors reminding us to keep silent or dress modestly. Considering the massive inflow of tourists from a variety of cultural backgrounds such simple messages are obviously insufficient today. On the other hand, it is interesting that similar requests and warnings are less often found on the doors of museums, concert halls or theatres. Is this only because porters and security men there keep an eye on visitors? It seems that contemporary man is changing. Not only is "culturally appropriate' behaviour becoming rare but man lacks a sense of the sacrum as well. 
$\mathrm{z}$ innymi obiektami nawet najbardziej czcigodnymi, należącymi jednak do świeckiej sfery? Co stanowi wyróżnik turystyki kierującej się ku wielkim sanktuariom, katedrom, ale i małym wiejskim kościółkom, a nawet przydrożnym kapliczkom?

W celu sformułowania odpowiedzi na postawione zagadnienie trzeba odnieść się przynajmniej do dwóch przesłanek. Mianowicie zdać sobie sprawę $\mathrm{z}$ podstawowego sensu istnienia religijnych i sakralnych budowli. Po wtóre, określić cele turystyki $\mathrm{z}$ chrześcijańskiego punktu widzenia. Na wstępie zastrzegamy, iż artykuł traktuje o świętych miejscach chrześcijaństwa. Mutatis mutandis można obserwacje i wnioski w nim zawarte ukierunkować ku budowlom innych religii.

\section{SENS ISTNIENIA RELIGIJNYCH OBIEKTÓw}

Użyliśmy przed chwilą dwóch sformułowań: budowle sakralne i budowle religijne. Rozróżnienie nie jest przypadkowe. Chodzi nam o uświadomienie, iż te pierwsze powstały w celu wyłącznie kultycznym. Należą do nich kościoły, kaplice bądź inne miejsca modlitwy. Do nich można w dosłownym sensie odnosić pojęcie sacrum. Istnieje też wiele innych obiektów nie przeznaczonych do sprawowania kultu, jednakże w bardziej lub mniej bezpośredni sposób odnoszących się do niego. Do tej ostatniej kategorii można zaliczyć np. klasztory, przykościelne dziedzińce, domy pielgrzyma lub domy parafialne. W jakimś sensie stoją one na pograniczu sacrum i profanum. Rozgrywa się w nich wiele świeckich czynności lecz także aktów, które przygotowują do kultu i podprowadzają do niego. Stąd też i pośród nich znajdziemy wiele znaków sacrum. Refektarze, korytarze klasztorne, domy parafialne pełne są religijnych przedstawień. Spełnia się w nich wiele prozaicznych, świeckich czynności. Ale też tutaj mają miejsce modlitwa, pobożny śpiew bądź inne podobne religijne formy. Jakby sacrum otwierało się ku codzienności, ku profanum. Każdy z owych przypadków trzeba rozważyć osobno. Niekiedy bowiem trudno jest precyzyjnie wyznaczyć granicę między obydwiema sferami.

Pojęcie sacrum - mówiąc skrótowo - stosowane jest w teologii do tego wszystkiego, co zwiazane jest $\mathrm{z}$ nadprzyrodzona, transcendentną sfera. $\mathrm{Z}$ tym co zostało wydzielone ze sfery świeckiej
Tourists often want to visit sites associated with religion. Can such visits be undertaken in the same way as to other sites, venerable as they may be, but still belonging to the secular world? What makes tourism oriented towards the great sanctuaries and cathedrals, as well as small country churches and wayside chapels, different?

In order to answer this question it is necessary to refer to at least two aspects: firstly, we must understand the basic significance of religious and sacred sites; secondly, we must define the aims of tourism from a Christian point of view. The author stresses at this point the fact that the article refers to the sacred sites of Christianity, although observations and conclusions could also be applied to sites of other religions.

\section{THE SIGNIFICANCE OF RELIGIOUS SITES}

Two separate terms have been used: sacred sites and religious sites; and the differentiation is not accidental. The former were built purely for the purposes of worship and include churches, chapels and other places of prayer. The notion of the sacrum refers directly to them. There are also many other sites which in practice are not used for those purposes but the sacrum also to some extent refers to them. We can mention here monasteries, churchyards, pilgrim refuges and parish offices. In a sense they stand closer to the boundary between the sacrum and the profanum. Many secular activities take place in them, but also activities which prepare people for worship and lead them towards it. Therefore, we can find many signs of the sacrum among them as well. Refectories, monastery cloisters and parish offices are full of religious imagery. Apart from the many prosaic secular activities, they are places of prayer, the singing of hymns and similar religious practices. It seems as if the sacrum is being opened to everyday reality, to the profanum. Each of these 
określanej mianem profanum. Od najdawniejszych czasów istniał zwyczaj otaczania religijnych obiektów murami. Bez względu na to, czy są to mury $w$ dosłownym znaczeniu, czy też jawią się za pomocą jakiejś innej, choćby tylko symbolicznej linii (pas zieleni, schody, wieniec religijnych znaków), wyznaczają one granicę pomiędzy tym, co świeckie (profanum) i tym co przeznaczone jest dla Boga (sacrum). W ich obrębie człowiek ma przybliżać się do Boga i spotykać się bezpośrednio z Nim. Wszystko to, co odgrywa się wewnątrz, ma służyć owemu spotkaniu, tworząc atmosferę świętości: symbolika, kształt i wystrój budowli, jej wyposażenie, barwy, ogrom, tajemniczość, często gra świateł, dym kadzidła, dźwięki dzwonów, gra organów; wreszcie piękno samej natury otaczające zabudowania (ogrody, parki w sanktuariach). Tutaj człowiek zobowiązany jest do innego niż „na zewnątrz” stylu bycia: zachowania ciszy, skupienia, odpowiedniego ubioru. Sposób zachowania ma również sprzyjać spotkaniu ze świętym. Zachowanie owych zasad ma pomagać w usuwaniu wszystkiego, co mogłoby rozproszyć uwagę i przeszkodzić $w$ duchowej koncentracji. Przechodząc przez ową granicę, człowiek ma stanąć w przestrzeni, która ma odmienne znaczenie, poddać się temu, co rozgrywa się wewnątrz. Stać się słuchaczem i uczniem, więcej współuczestnikiem religijnego dramatu. Przechodzeniu granicy często towarzyszą zewnętrzne znaki mające uświadomić wagę momentu, np. zakreślenie znaku krzyża na czole, użycie wody święconej, uklęknięcie. W pielgrzymkach znany jest zwyczaj tzw. liturgii progu, podczas której pątnicy wykonują szereg gestów wyrażających przekonanie, iż przekraczają oni bramę tego, co Święte (Kongregacja ds. Kultu Bożego, 2003).

Nie jest to jednak spotkanie bezosobowe $\mathrm{z}$ bogactwem bądź co bądź martwych przedmiotów. Wszystkie one są narzędziem służącym czemuś głębszemu: spotkaniu z żywą rzeczywistością Boga i Jego Świętych pośredników. A więc człowiek czuje się wezwany do otwarcia swego serca ku temu, co nadprzyrodzone: w zachwycie, uwielbieniu i osobistym oddaniu. Wewnątrz sakralnej przestrzeni mają miejsce akty wiary.

Znakomita część religijnych i sakralnych obiektów stanowi zarazem skarbiec kultury wyrażonej $w$ architekturze, rzeźbie, malarstwie i wielu innych dziedzinach sztuki. Stąd też stają się one częstszym celem turystyki. Sobór Watykański II w pierwszym swoim dokumencie Konstytucji o liturgii świętej wyjaśnia sens istnienia sztuki religij- cases however should be considered separately because it is difficult sometimes to draw the line between these two spheres.

The notion of the sacrum, to put it briefly, is used in theology to refer to all things associated with the supernatural transcendental sphere, separated from the secular world, which is described as the profanum. The custom of surrounding religious sites with walls is centuries old. Regardless of whether these are actual or symbolic walls (a wide strip of grass, steps, a row of religious symbols, etc.), they mark the border between the secular (the profanum) and that which is devoted to God (the sacrum). Within these walls man is expected to come nearer God and meet Him directly. Everything that goes on inside should enhance this encounter by creating an atmosphere of holiness: the symbolism, shape and appearance of the site, its furnishing, coloration, the vastness, mystery, the play of light, the incense, the sound of bells, organ music, and finally the beauty of the surroundings (the gardens and parks in sanctuaries). Here someone feels obliged to behave differently to the 'outside', to be quiet, focused and dress appropriately. Behaviour is also important when confronted with the sacrum. Abiding by these rules we get rid of everything that might distract us and disturb our spiritual concentration. Having crossed the line, man is supposed to be standing in a space which has a different meaning, submit to what is happening inside himself, to become a listener or a 'pupil' and to participate in the religious 'drama'. The crossing of the border is often accompanied by gestures which make the importance of the moment obvious, such as making the sign of the cross on the forehead, using holy water or kneeling. On pilgrimage there is a custom called the "liturgy of the threshold' where pilgrims make a series of gestures to express their belief that they are passing the doors to the sacrum (Congregation for Divine Worship, 2003).

However it is not an impersonal encounter with the richness of inanimate objects. All of them serve something more 
nej, której szczyt stanowi według niego sztuka sakralna. Istotą sakralnej sztuki jest dążenie do wyrażenia $w$ jakiś sposób $w$ dziełach ludzkich nieskończonego piękna Bożego. Przedmioty do niej należące stanowią znaki nadziemskich rzeczywistości. Jednakże według cytowanego dokumentu nie chodzi tu wyłącznie o symbolikę, która służy intelektualnemu poznaniu bądź estetycznym przeżyciom. Zadaniem sakralnej sztuki jest poruszenie serc ludzi, którzy z nią obcują, pociąganie człowieka ku wierze w Boga, skłanianie go do aktów uwielbienia i pomnażania Jego czci. Tu autorzy konstytucji wyjaśniają pierwotny cel, jaki nadali swoim dziełom artyści tworzący sakralną sztukę. Mówią o „wspaniałym hymnie chwały, jaki w minionych wiekach najwięksi artyści wyśpiewywali na cześć katolickiej wiary". W innym miejscu cytowanej konstytucji, sobór wspominając o artystach, którzy swój talent oddają Kościołowi, zachęca do tego, by ich praca stanowiła ,pewnego rodzaju naśladowanie Boga Stwórcy". W swej twórczości powinni oni pamiętać, że dzieła, które tworzą, służą „kultowi katolickiemu, zbudowaniu wiernych i pogłębieniu ich pobożności oraz formacji religijnej" (Konstytucja o liturgii, 2002).

Rzeczony wątek pogłębia nowy Katechizm Kościoła katolickiego, mówiąc o swoistym powołaniu sztuki kościelnej. Chodzi tu o powołanie twórców tejże sztuki: architektów, malarzy, rzeźbiarzy, budowniczych, muzyków (ściśle mówiąc, tylko człowiek może być powołany do jakiegoś dzieła). Powołanie w myśl kościelnego nauczania jest wezwaniem skierowanym do człowieka ze strony Boga. Przez adekwatną odpowiedź i realizację zadań związanych z tymże wezwaniem, chrześcijanin realizuje swoje człowieczeństwo w najgłębszym tego słowa znaczeniu. Otóż przywołany katechizm wskazuje, iż właściwym powołaniem sakralnej sztuki jest ,ukazywanie i uwielbienie, $w$ wierze $\mathrm{i}$ adoracji, transcendentnej tajemnicy Boga, niewidzialnego, najwyższego piękna Prawdy i Miłości, objawionego w Chrystusie”. Tylko tą drogą staje się ona ,prawdziwa i piękna”.

Przytoczone powyżej teksty mówią dobitnie o pierwszym i podstawowym zadaniu, jakie pełnią interesujące nas obiekty sakralne, a mianowicie funkcji religijnej. Służą więc temu, ku czemu w istocie swej zmierza każda religia: odkrywaniu rzeczywistości pozaziemskich - transcendentnych - i zwracaniu człowieka ku tym rzeczywistościom. W przestrzeni owych budowli człowiek spotyka się z Bogiem. Przez swą zawartość profound: an experience of the living reality of God and His holy interceders. Man feels summoned to open his heart to what is supernatural, in awe, admiration and personal devotion. In the inner sacred space acts of faith can happen.

The large number of religious and sacred sites are a treasury of culture, manifested through architecture, sculpture, painting and many other art forms. Therefore they frequently become objects of tourist interest. In its first document, entitled Constitution on the Sacred Liturgy, the $2^{\text {nd }}$ Vatican Council explains the significance of religious art and its highest form: sacred art. The essence of this sacred art is an attempt to express somehow, through human creation, God's endless beauty. Objects which are part of sacred art are signs of supernatural reality. However, according to the document, it is not only of symbolic importance, but serves intellectual or aesthetic experience. The main objective of sacred art is to move the hearts of those in front of it, to pull man towards faith in God, to encourage him to admire and pay homage. The authors of the Constitution explain the primary aim of those artists who produce sacred art and speak of a "magnificent hymn of praise sung by the greatest artists of past centuries to the Catholic faith". In another part of the Constitution, the Council mentions artists who devote their talent to the Church and encourages them, in a sense, to imitate God, their Maker. In their act of creation they should remember that their art serves "the Catholic cult, strengthening its followers and deepening their piety and religious formation" (Constitution on the sacred liturgy, 2002).

This line of thinking is continued in the new catechism of the Catholic Church on the role of ecclesiastical art. Only man is capable of producing such art, including architects, painters, sculptors, builders and musicians. According to Church teaching, a vocation is a call from God to man. By answering this call and doing the task, a Christian fulfils his humanity in the deepest sense of the word. The catechism shows that the vocation of 
ułatwiają one wyjście człowieka ku Bogu. Zarazem pełną funkcję religino-wychowawczą (formacyjna). Treści w nich zawarte przygotowują wychowują do odkrywania Bożych rzeczywistości i spotkania z żywym Bogiem. Wszystkie inne funkcje sakralnej sztuki winny być rozumiane $w$ relacji do tej pierwszej i podstawowej. Mają w jakiś sposób nie tylko z niej wynikać, ale ku niej prowadzić. Pominięcie funkcji religijnej będzie zawsze zapoznaniem wewnętrznej prawdy związanej z sakralnym obiektem. Nie zrozumie się zarazem pełnego znaczenia sakralnych i religijnych obiektów bez wiary.

Przypomnijmy w tym miejscu przemówienie Jana Pawła II podczas poświęcenia kościoła Matki Bożej Fatimskiej na Krzeptówkach w Zakopanem, 7 czerwca 1997 r. Stanowi ono trafne objaśnienie omawianej kwestii. Papież zwracając uwagę na piękno i kunsztowność sakralnych budowli, „prawdziwych skarbów architektury”, wyjaśnia sens istnienia każdej chrześcijańskiej świątyni. Nawiązuje też do innych obiektów chrześcijańskiej pobożności: przydrożnych krzyży, kapliczek i cmentarzy. W myśl słów Ojca Świętego każdy Z nich jest miejscem, w którym koncentruje się i odzwierciedla życie poszczególnego chrześcijanina oraz całej kościelnej wspólnoty. Papież mówi o przestrzeni, która ma być poświęcona - konsekrowana, czyli wyjęta z codziennego użytku i oddana Bogu. Odtąd stanowi ona miejsce Jego bytności - szczególnej obecności sacrum. Zarazem oddana jest ona wspólnocie ludzi wierzących, którzy tam właśnie gromadzą się i modlą, oddając kult Bogu (JAN PAWEE II 1997).

Niezwykle ważną sprawą poruszoną w przemówieniu jest prawda o głębokim związku świątyni z nieprzerwanie pulsującym w jej wnętrzu życiem Kościoła i poszczególnych jego członków. Nie jest to budowla „martwa”, twór muzealny wyjęty z życiowego kontekstu. W myśl Jana Pawła II, można mówić o potrójnym znaczeniu każdego sakralnego obiektu. Po pierwsze, nawiązuje on do przeszłości: „Stanowi wspaniały pomnik żywej wiary”. Tę przeszłość przechowuje i poucza o niej. Nie jest to jednak wyłącznie opowiadanie, lecz nawiązanie do ciągle żywej i dynamicznej tradycji. W historię wpisuje się teraźniejszość stanowiąca kontynuację przeszłości. Historia sakralnych budowli nie jest więc egzystencjalnie obojętna dzisiejszemu człowiekowi. W niej odnajduje on swoje korzenie, a przez to własną tożsamość. Są to korzenie wiary, która żyła wśród przodków i jest dziedzictwem współczesnych. sacred art is "showing and admiring, in faith and in adoration, the transcendent mystery of God, the invisible, ultimate beauty of Truth and Love as revealed in Christ". Only in this way does it become "true and beautiful".

The texts quoted above clearly illustrate the primary function of sacred sites the religious function. The sites serve the purpose of discovering transcendent realities and directing man towards them, as any religion does. Within the space of these sites man meets God. They facilitate man's journey towards God by what they contain and at the same time they have a religious and educational function. The message they carry prepares man to discover the divine reality and meet the living God. All other functions of sacred art should be subordinated to the primary one, and not only lead from it but also towards it. Ignoring the religious function will always mean obscuring the inner truth of a sacred site as their full significance will not be understood without faith.

Let us recall here what John Paul II said while consecrating the church of Our Lady of Fatima in Krzeptowki in Zakopane, on June $7^{\text {th }} 1997$ as his speech clearly explains the issue we are discussing here. Drawing our attention to the beauty and mystery of sacred sites ("true architectural treasures"), the Pope explained the significance of every Christian shrine, also referring to other symbols of Christian piety: wayside crosses, chapels and cemeteries. According to the Pope, each is a place where the life of an individual Christian and the whole church is centred and reflected. The Pope spoke about a space which is to be consecrated, excluded from everyday use and given to God. It is a space where He is present a very particular presence of the sacrum. It is also given to the faithful, the people who gather there to pray and worship (JOHN PAUL II 1997).

An unusual and very important matter mentioned in the speech is the truth about the deep bond between the place of worship and the ever-present life of the Church and its members. It is not 
Papież mówi dalej, iż w każdej świątyni aktualnie - teraz - rozgrywają się istotne dla życia każdego chrześcijanina wydarzenia. Tu zostaje on ochrzczony - włączony do żywego Kościoła. Tu przeżywa kolejne uroczystości związane $\mathrm{z}$ rokiem kościelnym, stając się poniekąd współbohaterem toczącej się historii zbawienia. Spotyka się z Bogiem, który obdarza go swą łaską poprzez sprawowane sakramenty, zwłaszcza ofiarę mszy świętej. W świątyni chrześcijanin wchodzi także w tajemnicę świętych obcowania - żywy kontakt ze świętymi. Kościoły zawierają nie tylko ich wyobrażenia $w$ postaci obrazów bądź relikwii. Nie tylko są im poświęcone poprzez nadany patronat, lecz mają być miejscem, gdzie chrześcijanin poleca się ich wstawiennictwu. Za ich przyczyną otrzymuje łaski i uczy się ich naśladować. A więc w sakralnych miejscach nieustannie „uaktualnia się" wspólnota Kościoła, pulsuje, rozwija się i umacnia życie wiary.

W myśl Jana Pawła II każda świątynia zwraca ku przyszłości i jej ostatecznemu wypełnieniu (przyszłość pozagrobowa). „Jak początek życia religijnego każdego wierzącego wiąże się z chrzcielnica, tak też jego kres, śmierć i pogrzeb również dokonują się w cieniu świątyni. Niejednokrotnie nawet cmentarze parafialne bezpośrednio przylegają do kościoła" - mówił w swej homilii Papież. Dramaturgia liturgii odbywającej się w świątyni połączona z zewnętrzną symboliką jej murów i wyposażenia przypominają człowiekowi o jego wiecznym przeznaczeniu i ostatecznym celu. Głębokie wczytanie się w tę prawdę nie pozwala mu zatrzymać się na tym, co doczesne i pokładać nadziei wyłącznie w tym, co przemijające.

Tu można odwołać się do innego papieskiego przesłania skierowanego do młodzieży. Mówiąc o dziedzictwie kultury, wskazał on młodym, iż mają je nie tylko poznać, ale samemu pielęgnować, ubogacić i przenieść w przyszłość (JAN PAWEe II 1985). Każde spotkanie z sakralnym zabytkiem powinno doprowadzić do odkrycia nici łączącej teraźniejszość wiary z jej przeszłością i przyszłością. Nie tylko dowieść, że nie można oddzielić od siebie tych etapów, ale także pokazać, że życie każdego $z$ nas jest wplecione w tę rzeczywistość.

Odwołajmy się w tym miejscu do praktycznej obserwacji, która może posłużyć lepszemu objaśnieniu omawianej kwestii. Współcześni znawcy sztuki czuwający nad jej ochroną oburzaja się często, jak mogło dojść do przebudowy wielu a lifeless, museum-like site taken out of the context of life. Following the Pope's line of thinking, there are three meanings to each sacred 'construction': first, it refers to the past by both preserving and teaching it - "a wonderful monument of living faith". However, it is not solely telling a story, but referring to a live and dynamic tradition as well. History overlaps with the present; being itself a continuation of the past. The history of sacred sites is not 'existentially indifferent' to contemporary man as roots are found in and through this to his own identity. The faith of our ancestors is our legacy.

The pope also says that every place of worship is a place where events essential for the life of every Christian take place. $\mathrm{He}$ is baptised there and admitted to the living Church. He participates in celebrations according to the church calendar, becoming a part of the ongoing history of salvation. He finds God who blesses him with His grace through the sacraments, especially Communion. In a place of worship a Christian learns the mystery of communion with the saints. Churches hold not only saints in the form of images or relics, and are not only devoted to their patron saint, but should be places where a Christian can seek intercession. He receives grace through them and learns how to follow their example. In sacred sites the church community is constantly brought 'up to date', developing and strengthening faith.

According to John Paul II, each place of worship looks to the future and its ultimate fulfilment in life after death. Similar to the beginning of every believer's religious life which takes place in the baptismal font, death and funerals also happen in the 'shadow' of a place of worship. "Even parish cemeteries are frequently adjacent to the church" - said the Pope in his homily. The drama of the liturgy in the place of worship, combined with the symbolism of its walls and interior, remind man of his ultimate goal. Considering this truth will not let him stop at the mundane level or trust only in transitory things.

We can refer here to another homily of the Pope, the one to the young. Speaking about cultural heritage, he said that they 
sakralnych obiektów, przy której doszło do bezpowrotnego zniszczenia starych form. Na stare obrazy nakładano nowe, przebudowywano ołtarze, powiększano przestrzenie świątyni. Dziś nie do pomyślenia jest, by kustosz zabytkowego obiektu dokonywał w nim zmian za wyjątkiem konserwacji istniejącej substancji bądź przywracania fragmentów z przeszłości. Wydaje się, że właśnie zaobserwowane fakty stanowią potwierdzenie naszych dotychczasowych wywodów. Żaden z sakralnych obiektów nie był budowany jako niezniszczalny pomnik sztuki, obiekt muzealny zmierzający li tylko do zachowania zabytków dla potomności. W ciagłych przeróbkach świątyń odzwierciedla się życie religijnej wspólnoty. Na przestrzeni historii trzeba było dokonywać ciagłych dostosowań do aktualnych religijnych potrzeb żywych ludzi. Życie religijne nie zamarło, lecz ciaggle posuwało się naprzód.

\section{ISTOTNE CELE TURYSTYKI}

W celu rozwiązania naszego problemu konieczne jest określenie najistotniejszych celów turystyki. Turystyka staje się dzisiaj jedną z bardzo dobrze prosperujących gałęzi przemysłu (przemysł turystyczny, biały przemysł). Ma to naturalnie duże znaczenie, zwłaszcza dla regionów przyjmujących ruch turystyczny. Daje miejsca pracy, okazję do uczciwego zarobku. Przyczynia się do podniesienia stopy życiowej miejscowych mieszkańców. Na owe walory zwracają uwage także oficjalne kościelne wypowiedzi (Papieska Rada ds. Duszpasterstwa Migrantów i Podróżnych, 2001). Do celów turystyki należy poznanie świata, zarówno natury, jak i kultury. Stanowi ona okazję do nawiązywania międzyludzkich kontaktów. Jest okresem fizycznej rekreacji. Należy jednak mocno podkreślić, iż istotne cele turystyki leżą $w$ głębszej sferze. Chodzi w niej przede wszystkim o kształtowanie samego człowieka - turysty. Turystyka niesie z sobą ogromne możliwości wychowawcze. Sa to szanse integralnego formowania człowieka, we wszystkich jego sferach: fizycznej, intelektualnej, duchowej, a także religijnej (OSTROwSKI 1996).

W kontekście naszego artykułu zapytajmy, $w$ jakim celu wprowadzamy turystę w obszar sakralnych obiektów. Zaznaczmy od razu, że nie chodzi nam o pielgrzymkę, która z natury swojej posiada ściśle religijne-kultyczne cele. Nie chce- should not only learn about it but also care for it, enrich it and carry it into the future (JOHN PAUL II 1985). Each encounter with a sacred historical monument should lead to the discovery of a link between the past, the present and the future of faith. It is not enough to prove these stages inseparable but to show that the life of each of us is woven into this reality.

A practical observation can be given which may help to explain the issue we are discussing better. Contemporary experts in art are often indignant about the 'reconstruction' of sacred sites which results in irreversible damage to the original form. In the past new pictures were painted on the old ones, altars were rebuilt, and the space of the place of worship enlarged. Today it is unthinkable for a museum curator to make any alteration apart from the conservation of the existing fabric or restoring fragments from the past. Observation seems to confirm the discussion here. No sacred site was erected as an indestructible eternal monument of art, a museum whose main aim is to preserve historical artefacts for future generations. Alterations in the place of worship reflect the life of the religious community. Over time it was necessary to make adjustments to current religious needs; religious life did not freeze, it constantly moved forward.

\section{THE ESSENTIAL AIMS OF TOURISM}

In order to resolve this problem it is necessary to define the main aims of tourism as it is today one of the most prosperous sectors of the economy. Naturally, this is important particularly for regions which receive tourists. It is a source of employment, gives an opportunity to make money honestly and increases the living standard of local inhabitants. These advantages have been mentioned in official church statements (The Pontifical Council for the Pastoral Care of Migrants and Itinerant People, 2001). The aims of tourism include learning about the world, both nature and culture, giving an opportunity to meet new people and offers a chance for physical recrea- 
my też w tym miejscu dyskutować nad problemem tzw. turystyki religijnej, która stoi niejako na pograniczu pielgrzymki i turystyki zakładającej „świeckie cele” (OSTROWSKI 2002). Turysta ma spotkać się $\mathrm{W}$ ich przestrzeni $\mathrm{z}$ wartościami, które stanowią bogactwo ducha i kultury wielu epok. Zaznaczyliśmy wcześniej, iż wiele z owych budowli należy do ważnych zabytków kultury. Odwiedziny są okazją do informacji, a więc zdobycia wiedzy, dzięki której poszerza on swe horyzonty poznawcze. $\mathrm{Z}$ takiego założenia wychodzi przewodnictwo, które stawia sobie za cel ukazanie turystom walorów historycznych, architektonicznych bądź artystycznych odwiedzanych obiektów. Z drugiej strony, w owym spotkaniu otwiera się szansa głębszych doświadczeń. Otóż obcowanie $\mathrm{z}$ wartościami połączone z głębszą refleksją, a nie tylko prostą obserwacją, jest zdolne przemienić samego człowieka, otworzyć go na bogactwo wartości, które odtąd stawać się będą jego osobistą własnością. Więcej, będą go wewnętrznie formować. W ten sposób turystyka ma szansę stawać się czynnikiem sprzyjającym urzeczywistnianiu pełni człowieczeństwa.

W kontekście naszego artykułu należy podkreślić, że spotkanie z zabytkowym obiektem sakralnym ma dopomóc turyście w odkryciu innego świata wartości, który znajduje się nie tylko ponad tym, co materialne, ale także tym, co ziemskie. Trzeba przywołać wszystko to, co powiedzieliśmy wyżej o znaczeniu sakralnych obiektów. Same w sobie stają się one rodzajem narzędzia skierowującego człowieka ku temu, co nadprzyrodzone. Owo spotkanie ma pomagać nie tylko w ,intelektualnym” obcowaniu z sacrum, ale poruszyć człowieka do żywego, osobowego dialogu ze świętym Bogiem. Wspomóc jego refleksję nad ostatecznym sensem i celem życia. Przed wchodzącym w świętą przestrzeń otwiera się więc szansa zasadniczych przewartościowań w dziedzinie wiary. Polski synod zauważa, iż z pozoru zwyczajna turystyczna wycieczka odpowiednio animowana może przekształcić się w pielgrzymkę, która prowadzi człowieka bliżej Boga (II Polski Synod Plenarny, 1999).

Z naszych rozważań nad rolą turystyki poruszającej się między profanum i sacrum rodzi się wiele wskazań dla jej animatorów. Ich działalność ma zmierzać ku takiemu kształtowaniu turystyki, by stawała się ona drogą wychowania człowieka. W pierwszym rzędzie winni oni dopomagać turystom, by odkrywali istotne, wymienione wy- tion. It must be pointed out, however, that the essential aims of tourism are much more profound and involve the shaping of the inner man. Tourism is a source of educational opportunity for forming the whole man in every aspect: physical, intellectual, spiritual and religious (OSTROWSKI 1996).

In the context of the article, let us ask why we take the tourist to the world of sacred sites, and by this we do not mean pilgrimage which by nature has aims that are strictly religious and connected to a cult. We do not want to discuss religious tourism here, which in a way lies somewhere between pilgrimage and tourism with 'secular aims' (OSTROWSKI 2002). The tourist will encounter values which reflect the spirit and culture of many epochs. We have mentioned before that many of these sites are important cultural monuments and a visit is an opportunity to learn something. The idea of a guided tour is to show tourists the historical, architectural or artistic assets of the sites visited. On the other hand, such a visit gives an opportunity to experience something deeper. Experience, combined with deeper reflection and not only simple observation, may change someone, open them to the richness of sacred values which can then be internalised. What is more, they will form his soul. In this way tourism can help man in his journey to full humanity.

It must be pointed out that an encounter with a historical sacred site can help the tourist to discover a different world of values, not only beyond the material but also the earthly sphere. We should recall everything said above about the significance of sacred sites as they have become a tool directing man towards the supernatural. A visit is not only to aid someone in the 'intellectual' encounter with the sacrum, but to encourage such a person to have a personal dialogue with God and reflect on the ultimate meaning and aim of life. A person entering sacred space has a chance to make basic changes in his approach to faith. The Polish Synod believes that if properly organised, a seemingly ordinary tourist excursion may be transformed into a pilgrimage leading the tourist closer to God (II Polski 
żej walory turystyki. Szczególnym zadaniem jest odsłanianie ,wewnętrznej prawdy" sakralnych budowli, istotnego sensu ich istnienia. Wprowadzanie $w$ misterium świętej przestrzeni, a nie zatrzymywanie się jedynie na tym co ,zewnętrzne” i zjawiskowe.

W tym miejscu trzeba zasygnalizować jedno z zagrożeń charakterystycznych dla współczesnej epoki, określane mianem praktycznego materializmu. Dotyka ono także świata turystyki. Materializm przejawia się między innymi w ujmowaniu wszystkiego co nas otacza w kategoriach ekonomicznych, w dążeniu do przeliczania wszystkich dostępnych człowiekowi wartości na materialne profity. Przy tego rodzaju podejściu zaczyna znikać z horyzontu sam człowiek z jego wyższymi celami. Owszem, uwzględnia się go jako konsumenta, któremu trzeba sprzedać towar najwyższej jakości i uzyskać jak największe dochody. Mówi się więc o turystyce wyłącznie w kategoriach ,produktu”, gubiąc gdzieś jej duchowe i wychowawcze walory. Problem zaczyna pojawiać się ze zdwojoną siła, gdy zaczynamy traktować o turystyce kierującej się ku obiektom sakralnym. Całkowitą hybrydą staje się np. określanie pielgrzymek w kategoriach turystycznego produktu. Czy coś, co jest święte, wyjęte z codziennego użytku, staje się de facto profanum - towarem sprzedawanym ciekawym nowych doznań tłumom? Czy można zapomnieć o człowieku, który wchodzi w obręb sacrum przede wszystkim po to, by samemu zaczerpnąć coś z tego, co nadprzyrodzone, i by stawać się bogatszym duchowo?

Nasuwa się tu jeszcze jedna uwaga, która pomoże lepiej zrozumieć rozważane zagadnienie. Częstym grzechem współczesnego stylu turystyki jest pośpiech. W kontekście zagadnienia wolnego czasu, którego częścią jest turystyka, mówi się o tzw. „neurozie niedzielnej”. Mutatis mutandis można traktować o „neurozie turystyki”. Pragnieniem turysty jest wyjechać jak najdalej, oglądnąć jak najwięcej i doznać jak najmocniejszych wrażeń. Powoduje to $w$ istocie powierzchowność W odbiorze wartości, z którymi spotyka się on na turystycznych szlakach (Kongregacja ds. Duchowieństwa, 1969). Niekiedy przyczyną tego rodzaju sytuacji jest program ofiarowany przez animatorów turystyki, pragnących poniekąd „wykazać się” przed klientem, że sprzedają mu jak najwięcej i najlepszego towaru, za który przecież solidnie zapłacił. Dość często obserwujemy przewodników, którzy prawdopodobnie $\mathrm{z}$ tych samych przyczyn zarzucają turystów ogromną liczbą szczegółów:
Synod Plenarny - 2nd Polish Plenary Synod, 1999).

The discussion of the role of tourism between profanum and sacrum results in several suggestions for organisers whose activity should be making tourism a tool for education. They should above all help tourists discover the significance of tourism sites. A particular challenge is to discover the 'inner truth' of sacred sites - the meaning of their existence - to lead people to the mystery of sacred space and not just stop at the 'external'.

At this point we should point out a danger typical of contemporary times which also concerns the world of tourism: materialism. This can be seen in the economic approach to everything which surrounds us, considering value in terms of material profit. With this sort of approach, man himself and his higher aims begin to disappear. He is only taken into account as a consumer who must be offered goods of the highest quality, and bring in the highest possible income. Tourism is discussed solely as a product, and spiritual and educational values get lost somewhere along the way. The problem becomes more serious when we talk about tourism in sacred sites. To define pilgrimage as a tourist product is a hybrid. Is something sacred taken out of the everyday use a product sold to crowds longing for new experience? Can we forget about man who enters the sacrum above all to share something supernatural and become spiritually richer?

There is one more thing that may help understand the problem. Haste is a sin frequently committed in contemporary tourism. In reference to leisure time, which is partly occupied by tourism, we can speak about 'Sunday neurosis'. Mutatis mutandis it can be treated more widely as 'tourism neurosis'. A tourist wishes to travel as far as possible, see as much as possible and live through the strongest experiences possible. This makes the experience he gains on a journey superficial (Congregation for the Clergy 1969). Sometimes such a situation is caused by the organisers who want to prove that they are selling the best product, worth the 
opisów, dat i nazwisk. Rzadziej jednak posiadają umiejętność wprowadzania w najgłębszy sens istnienia odwiedzanych miejsc, o którym mówiliśmy przed chwilą. Innym razem, wybierając może prostszą drogę, podchlebiają jedynie powierzchownej ciekawości turystów, nie wymagając od nich większego duchowego wysiłku. Bo przecież próba dotarcia ku głębszym wartościom kosztuje. W tym wszystkim trudno mówić o wejściu „w głąb”, które wymaga zarówno odpowiedniego nastawienia, jak i spokojnego czasu, odpowiedniego wprowadzenia, ale i okazji do osobistej refleksji. Gdy mówimy o obiektach sakralnych, może się okazać, że tego rodzaju pośpieszna, „przeładowana” turystyka pozostanie „na zewnątrz”, w sferze profanum. Nie dotrze „w głąb”, czyli do sacrum.

\section{KILKA PRAKTYCZNYCH WNIOSKÓW}

Strona kościelna chce udostępnić do zwiedzania znajdujące się pod jej opieką sakralne zabytki. Zawierają one walory, które są własnością nie tylko Kościoła, ale i całego społeczeństwa. Stanowią one globalne dziedzictwo lokalnej wspólnoty i całej ludzkiej społeczności, będąc jedną z najznakomitszych części dorobku kultury. We Wskazaniach dla duszpasterstwa turystycznego znajdujemy wytyczną ze strony Stolicy Apostolskiej, zarządzającej, by ,miejsca kultu pozostawały otwarte przez cały dzień dla krzewienia pobożności wiernych oraz dla umożliwienia obejrzenia znajdujących się tam wybitnych dzieł sztuki”. Zauważamy równocześnie, iż owo zarządzenie mimo wszystko na pierwszym miejscu wskazuje istotny cel udostępniania sakralnych miejsc, jakim jest rozwój pobożności wiernych (Kongregacja ds. Duchowieństwa, 1969).

Nie można się przy tej okazji oprzeć przed wypowiedzeniem zdania, które zabrzmi jak pochwała. $\mathrm{Na}$ tle niektórych innych religii chrześcijaństwo wykazuje w tym wypadku wielką otwartość. Znane są fakty izolowania świętych miejsc przed profanami - niewiernymi i wyznawcami obcych religii. Miejsca święte chrześcijan nie są zamykane przed nieznajomymi. Przez owo otwarcie bynajmniej nie tracą swego sacrum i nie stają się obszarami świeckimi.

Kościół jednakże chce udostępniać swoje święte przestrzenie pod określonymi warunkami. Ma do tego prawo jako strażnik sacrum. $\mathrm{Z}$ teologicznego punktu widzenia jest on nie tyle właścicie- money paid. Guides who bombard tourists with detailed descriptions, dates and names are commonly found, however, they are rarely able to lead us through the more profound sense of the visited sites. An attempt to reach higher values needs an effort to be made. In such a situation it is difficult to go deep inside, as this requires an appropriate attitude and introduction, time and a chance for personal reflection. When we talk about sacred sites, it may turn out that this hasty, overloaded tourism will stay 'outside', in the sphere of the profanum. It will not reach the 'inside', into the sacrum.

\section{A FEW PRACTICAL CONCLUSIONS}

The church wants to make its sacred sites available for tourists as the sites have assets which belong not only to the Church but to the whole society. Being one of the most valuable parts of culture they are a global legacy, both of the local community and the whole of humanity. In Directions for a Ministry of Tourism we find a recommendation by the Vatican to "leave cult sites open so as to spread piety and enable the exquisite pieces of art which are there to be seen". This recommendation gives priority to the primary aim of making sacred sites available to the public, the strengthening of piety among believers (Congregation for the Clergy 1969).

It is hard to restrain oneself from a comment at this point which will sound like praise; compared with some other religions, Christianity seems very open. Cases of guarding sacred sites against outsiders - the unfaithful followers of other religions - are well known. Christian sacred sites are not closed to strangers - they do not lose their sacrum by being open nor do they become secular.

However, the Church is only willing to open its sacred spaces under certain conditions, and it has its rights as the guardian of the sacrum. From the theological point of view, the Church is not as much the owner as the 'guardian' of what is sacred, otherwise it would be neglecting one of its 
lem, ile depozytariuszem tego co święte. Gdyby przestał być kustoszem sacrum, sprzeniewierzyłby się jednemu ze swych ważnych zadań. Na pierwsze miejsce wysuwa się potrzeba zabezpieczenia odpowiedniego szacunku do tego, co święte. Wiele zależy tu od świadomości i postaw osób odwiedzających sakralny obiekt. Sprawy nie da się załatwić wyłącznie nakazami bądź zakazami, postawieniem większej liczby stróżów, tablic informacyjnych lub alarmów. Istotnym zadaniem jest formowanie człowieka i jego wewnętrznych przekonań. Szacunek do świętego miejsca rodzi się z poczucia sacrum. Jeśli już nie wypływa ono z religijnych motywów, winno przynajmniej rodzić się $\mathrm{z}$ odpowiednio ukształtowanej osobistej kultury. Brak poczucia sacrum jest jakimś znakiem duchowej degradacji człowieka.

W dobie ogólnego kryzysu kultury i wielu wyższych wartości oraz powszechnego zeświecczenia ów wychowawczy proces nie jest bynajmniej łatwym zadaniem. Sam Kościół powinien więcej uwagi poświęcić tej sprawie $w$ formacyjnej pracy wśród swych wyznawców. Bo i na tym polu pozostaje wiele do życzenia. Globalne procesy mają swój wpływ także na postawy najbardziej wierzących osób. Jest to też zadanie wszystkich animatorów turystyki. W dziedzinie tej istnieje ciągle szerokie pole do współpracy strony świeckiej i kościelnej.

Formy szacunku wobec świętego miejsca mogą naturalnie zmieniać się $w$ zależności od epoki i panujących w niej zwyczajów. Trzeba zaznaczyć, że to nie Bóg gorszy się ludzkim zachowaniem, lecz sami ludzie wierzący, którzy przyjęli określone formy czci i uszanowania wobec Boga. W wypadku turystyki wchodzącej w świętą dla religii przeStrzeń należy mieć na względzie aktualnie przyjęte, lokalne obyczaje zachowań.

Chrześcijanie mają zawsze w oczach obraz Chrystusa, który dbał o świętość bożego domu. A czynił to niekiedy drastycznymi metodami, siłą wyrzucając ze świątyni kupczących, określając, iż uczynili ją przez swój brak szacunku jaskinią zbójców (Łk 19, 46). Innym razem przestrzegał, by nie rzucać pereł przed wieprze i nie dawać psom tego, co święte (Mt 7, 6).

Zatem, jak zauważamy, Kościół kieruje się w interesującej nas kwestii troską o właściwe wychowanie człowieka. Zależy mu na tym, by człoWiek odwiedzając miejsca święte czynił to z jak największym pożytkiem i by wyszedł stamtąd Wszechstronnie ubogacony. Przede wszystkim przeniknięty sacrum - świętszy. important duties, which is to secure respect for the sacrum. A lot depends here on the awareness and attitudes of the visitors to a sacred site. The problem cannot be solved by means of regulations, guards, information boards or alarm systems as the important task is to form the inner man and his beliefs. Respect for a sacred place comes from the sense of the sacrum. If this sense does not originate from religious motives, it should at least come from an appropriate 'personal culture'. The lack of a sense of the sacrum is in a way a sign of spiritual degradation.

Nowadays, when culture and higher values are undergoing a crisis, and at a time of widespread secularisation, this educational process is by no means easy. The Church itself should devote more attention to this problem among its followers. Global processes affect the attitudes of the strongest believers. It is also a task for all tourism organisers as in this field there is still a chance for cooperation between the secular side and the Church.

The forms of respect for sacred sites may of course change, depending on the epoch and its customs. It must be pointed out that it is not God who is indignant at human behaviour, but the believers who have adopted certain forms of showing reverence and respect for God. Where tourism enters sacred space, currently accepted local customs should be taken into account.

Christians always remember Christ who cared for the holiness of the place of worship. He did it sometimes using drastic methods such as throwing the traders out of the temple and saying that their lack of respect had made it a "den of thieves" (St Luke 19: 46). On another occasion he warned against giving to dogs what is sacred (St Matthew 7: 6).

The Church is guided by a care for the education of the whole person. It is important that a tourist who visits a sacred site should do it for his own growth and leave it richer, saturated with the sacrum.

We have used the term 'tourism product' in the article, a term often used in 
Padło w naszym artykule określenie - często dziś używane w świecie turystyki - ,produkt turystyczny". Nie będziemy się spierali co do jego zasadności w określonych ramach turystycznego przemysłu, natomiast trzeba wyrazić poważne zastrzeżenie co do stosowania go w odniesieniu do sakralnych obiektów stających się częstym celem turystyki. Nie wolno nam patrzyć na religijne budowle jako na zabytki przeszłości, które z zyskiem sprzedaje się na turystycznym rynku. Tego rodzaju spojrzenie „bez ducha” będzie śmiercią dla prawdziwej turystyki i dla jej wychowawczych walorów. Powiedzmy szerzej, śmiercią dla duchowej kultury, która przecieź jest kulturą przez to, że odnosi do najgłębszych warstw ludzkiego ducha. the world of tourism today and will not argue whether it should be used in reference to the tourism industry or not. However, there are serious reservations as to its application to those sacred sites which are frequently visited by tourists. We must not look on religious sites as historical monuments from the past, sold on the tourist market for profit as this kind of approach will mean death to genuine tourism and its educational values; and it will mean death to the spiritual culture which appeals to the deepest part of human soul.

\section{BIBLIOGRAFIA - BIBLIOGRAPHY}

Ewangelizacja kultury $i$ środków społecznego przekazu [w:] II Polski Synod Plenarny (1991-1999), Poznań 2001. s. 101-124.

JAN PAWEL II, 1985, List do mtodych całego świata, 31 marca 1985 r., Kraków.

Jan Pawel II, 1997, Homilia podczas Mszy św. i konsekracji kościoła Matki Bożej Fatimskiej, "L'Osservatore Romano", numer specjalny polskiego wydania, $31 \mathrm{ma}-$ ja - 10 czerwca 1997 r., s. 72-75.

Katechizm Kościoła katolickiego, Poznań 1994.

Kongregacja ds. Duchowieństwa, Wskazania ogólne dla duszpasterstwa turystycznego (27 marca 1969 r.), „Miesięcznik Diecezjalny Gdański”, nr 15 (1971) 8-9. s. 268-285.

Kongregacja ds. Kultu Bożego i Dyscypliny Sakramentów. Dyrektorium o pobożności ludowej $i$ liturgii, 17 grudnia 2001 r., Poznañ 2003.
Konstytucja o liturgii świẹtej „Sacrosanctum concilium”, [w:] Sobór Watykański II. Konstytucje, dekrety, deklaracje, Poznań 2002, s. 25-76.

Ostrowski M., 2002, Pilgern oder religiöser Tourismus, [w:] Il Santuario, spazio per un'accgilenza fraterna $e$ universale, Città del Vaticano, s. 41-52.

OSTROWSKI M., 1996, Duszpasterstwo wobec problemu wolnego czasu człowieka. Aspekt moralno-pastoralny ze szczególnym uwzględnieniem zagadnien turystyki. Kraków.

Papieska Rada ds. Duszpasterstwa Migrantów i Podróżnych, Wskazania dla duszpasterstwa turystycznego. 29 czerwca 2001 r., [w:] Duszpasterstwo pielgrzymów $i$ turystów. Wybór wypowiedzi i dokumentów kościelnych, opr. M. Ostrowski, Kraków 2003, s. 132-182. 